\title{
Isolation of Adenosine and Cordysinin B from Anredera cordifolia that Stimulates CRE-Mediated Transcription in PC12 Cells
}

\section{(ㄷ) (i)}

\author{
Authors \\ Yasushi Ohizumi ${ }^{1}$, Michi Kawada', Maki Kamada', Akira Nakajima1, 2, Koji Kajima³, Nobuyuki Uozumi", \\ Yasumasa Hara ${ }^{5}$, Yuanqiang Guo ${ }^{6}$, Masami Ishibashi ${ }^{5}$
}

\section{Affiliations}

1 Kansei Fukushi Research Institute, Tohoku Fukushi University, Aoba-ku, Sendai, Japan

2 Department of Applied Biology and Food Sciences, Faculty of Agriculture and Life Science, Hirosaki University, Hirosaki, Aomori, Japan

3 Sankyo Co., Ltd., Fuji, Shizuoka, Japan

4 Department of Biomolecular Engineering, Graduate School of Engineering, Tohoku University, Sendai, Japan

5 Graduate School of Pharmaceutical Sciences, Chiba University, Chuo-ku, Chiba, Japan

6 State Key Laboratory of Medicinal Chemical Biology, College of Pharmacy, and Tianjin Key Laboratory of Molecular Drug Research, Nankai University, Tianjin, China

Key words

Anredera cordifolia, Basellaceae, adenosine, cordysinin B, dementia, CRE-mediated transcription

received 08.10 .2020

revised 12.01.2021

accepted 17.02.2021

\section{Bibliography}

Planta Med Int Open 2021; 8: e19-e24

DOI 10.1055/a-1395-6510

ISSN 2509-9264

(C) 2021. The Author(s).

This is an open access article published by Thieme under the terms of the Creative Commons Attribution-NonDerivative-NonCommercial-License, permitting copying and reproduction so long as the original work is given appropriate credit. Contents may not be used for commercial purposes, or adapted, remixed, transformed or built upon. (https://creativecommons. org/licenses/by-nc-nd/4.0/)

Georg Thieme Verlag KG, Rüdigerstraße 14,

70469 Stuttgart, Germany

\section{Correspondence}

Prof. Dr. Yasushi Ohizumi

Kansei Fukushi, Research Institute, Tohoku Fukushi

University,

6-149-1 Kunimigaoka

Aoba-ku

989-3201 Sendai

Japan

Tel.: +8122728 6009, Fax: +81227286009

ohizumi@tfu-mail.tfu.ac.jp

Akira Nakajima, Ph.D.

Department of Applied Biology and Food Sciences, Faculty

of Agriculture and Life Science,

Hirosaki University,

3 Bunkyo-cho

Hirosaki

036-8561 Aomori

Japan

Tel.: + 81172393787

anakajim@hirosaki-u.ac.jp

丹 Supplementary material is available under http://doi: 10.1055/a-1395-6510

\begin{abstract}
Alzheimer's disease is a typical neurodegenerative disorder, and its prevention or treatment poses great concern in advanced countries. In our survey of numerous natural resources with neurotrophic activities, we found that Anredera cordifolia improved memory impairment and increased cyclic adenosine monophosphate (AMP) response element-mediated transcription, an important step in signal transduction for memory formation. The extracts of this food were dissolved in methanol and then partitioned with three organic solvents and water, separating into $n$-hexane, ethyl acetate, $n$-butanol, and water layers. The $n$-butanol layer with the strongest activity on cyclic AMPresponse element-dependent transcription was fractionated using silica gel column chromatography and then the activity was monitored using preparative high-performance liquid chromatography to give adenosine and cordysinin B, respectively. Both compounds showed a concentration-dependent
\end{abstract}


increase in cyclic AMP-response element-mediated transcription activity. These results suggest that both adenosine and cordysinin B may participate in improving the action of $A$. cordifolia on memory impairment, and these actions, at least in part, result from the activation of adenosine $A_{1}, A_{2 A}$, and $A_{2 B}$ receptors.

\begin{tabular}{|c|c|}
\hline \multicolumn{2}{|c|}{ ABBREVIATIONS } \\
\hline$A \beta$ & $\beta$-amyloid \\
\hline$A D$ & Alzheimer's disease \\
\hline AMP & adenosine monophosphate \\
\hline CAMP & cyclic AMP \\
\hline CRE & cAMP-response element \\
\hline CREB & cAMP-response element-binding protein \\
\hline EtOAc & ethyl acetate \\
\hline LTP & long-term potentiation \\
\hline MEAC & methanol extract of $A$. cordifolia \\
\hline $\mathrm{BuOH}$ & n-butanol \\
\hline NMDA & $N$-methyl-D-aspartate \\
\hline Nob & nobiletin \\
\hline
\end{tabular}

\section{Introduction}

$A D$ is the most common neurodegenerative disorder and has become a severe social problem in advanced countries [1]. However, effective preventive and fundamental therapeutic methods for $A D$ have not yet been established. Notably, $A \beta$ peptide in AD patients' brains decreases CREB signaling pathway activation to inhibit hippocampal LTP formation [2], and A $\beta$ oligomers inhibit CREB activation in hippocampal neurons [3]. Furthermore, the CREB/CRE pathway greatly contributes to LTP, a synaptic memory model, and memory formation in vivo [4-8].

Numerous natural resources have simultaneously provided useful pharmacological tools [9] and novel leading compounds for drug development [10]. We have reported that Nob, a polymethoxylated flavone from the peel of Citrus depressa, activates the CREB/CRE pathway in PC12D cells or cultured rat hippocampal neurons to exhibit memory-improving actions in various animal models of dementia [11-14].

There is considerable interest in identifying safe and effective compounds from natural resources that enhance the function of CREB transcription factor coupled with CRE-mediated transcription, which could improve memory deficits in AD.

In our survey of natural resources having the increasing action of the CRE-mediated transcription activity, we found that Anredera cordifolia, like Nob, enhances this activity and reverses memory impairment caused by NMDA receptor antagonist MK-801 in mice [15]. Alternatively, A. cordifolia possesses pharmacologically interesting actions such as anti-obesity, anti-hyperlipidemia, antihypertensive, antidiabetic, antioxidant, and anti-inflammatory activities [16, 17]. Here, we unprecedentedly described that adenosine and cordysinin $B$ are isolated as active ingredients from A. cordifolia, possessing increasing activity on CRE-mediated transcription. It is also suggested that these actions are caused by activating adenosine receptors.

\section{Results and Discussion}

$A D$ is the most common neurodegenerative disorder showing progressive loss of memory and cognitive function. Notably, late LTP formation, a synaptic memory model, is blocked by the $A \beta$ peptide by inhibiting the CREB signaling pathway [2]. Using a new strategy in our survey of numerous natural resources activating the CREB/ CRE pathway, we found that $A$. cordifolia, like Nob from citrus peels, with activating actions on CRE-mediated transcription, improved MK-801-induced memory impairment [13-15, 18].

A. cordifolia leaves $(202 \mathrm{~g}$ ) were extracted using $\mathrm{MeOH}(0.4 \mathrm{~L}$ ) for 5 days at room temperature in a stationary state to obtain the $\mathrm{MeOH}$ extract ( $47.5 \mathrm{~g}$ ) by removing the solvent using a rotary evaporator. The $\mathrm{MeOH}$ extracts were fractionated by monitoring the CRE-mediated transcriptional activity using PC12 cells as illustrated in $>$ Fig. 1. The four layers partitioned with $n$-hexane, EtOAc, and $\mathrm{BuOH}$ had CRE-mediated transcriptional activities [12.2-fold activation (BuOH layer), 4.4-fold activation (EtOAc layer), 1.5-fold activation ( $n$-hexane layer), and 1.3 -fold activation $\left(\mathrm{H}_{2} \mathrm{O}\right.$ layer) at $30 \mu \mathrm{g} / \mathrm{mL}$ ]. The BuOH layer (5.8 g) was subjected to silica gel $60 \mathrm{~N}$ column chromatography ( $445 \times 420 \mathrm{~mm}, \mathrm{CHCl}_{3}-\mathrm{MeOH}$ system) to give fractions $1 \mathrm{~A}\left(\mathrm{CHCl}_{3}: \mathrm{MeOH}=13: 1,0.27 \mathrm{~L} ; \mathrm{CHCl}_{3}: \mathrm{MeOH}=9: 1\right.$, $0.25 \mathrm{~L}), 1 \mathrm{~B}\left(\mathrm{CHCl}_{3}: \mathrm{MeOH}=9: 1,0.15 \mathrm{~L}\right), 1 \mathrm{C}\left(\mathrm{CHCl}_{3}: \mathrm{MeOH}=9: 1,0.1\right.$ $\left.\mathrm{L} ; \mathrm{CHCl}_{3}: \mathrm{MeOH}=7: 1,0.25 \mathrm{~L}\right), 1 \mathrm{D}\left(\mathrm{CHCl}_{3}: \mathrm{MeOH}=7: 1,0.05 \mathrm{~L}\right.$; $\left.\mathrm{CHCl}_{3}: \mathrm{MeOH}=5: 1,0.3 \mathrm{~L}\right), 1 \mathrm{E}\left(\mathrm{CHCl}_{3}: \mathrm{MeOH}=5: 1,0.15 \mathrm{~L}\right.$; $\left.\mathrm{CHCl}_{3}: \mathrm{MeOH}=3: 1,0.15 \mathrm{~L}\right), 1 \mathrm{~F}\left(\mathrm{CHCl}_{3}: \mathrm{MeOH}=3: 1,0.15 \mathrm{~L}\right), 1 \mathrm{G}$ $\left(\mathrm{CHCl}_{3}: \mathrm{MeOH}=3: 1,0.10 \mathrm{~L}\right), 1 \mathrm{H}\left(\mathrm{CHCl}_{3}: \mathrm{MeOH}=3: 1,0.15 \mathrm{~L}\right.$; $\left.\mathrm{CHCl}_{3}: \mathrm{MeOH}=2: 1,0.15 \mathrm{~L}\right), 1 \mathrm{(}\left(\mathrm{CHCl}_{3}: \mathrm{MeOH}=2: 1,0.20 \mathrm{~L}\right.$; $\left.\mathrm{CHCl}_{3}: \mathrm{MeOH}=1: 1,0.15 \mathrm{~L}\right), 1 \mathrm{~J}\left(\mathrm{CHCl}_{3}: \mathrm{MeOH}=1: 1,0.30 \mathrm{~L}\right)$, and $1 \mathrm{~K}$ $\left(\mathrm{CHCl}_{3}: \mathrm{MeOH}=1: 1,0.05 \mathrm{~L} ; \mathrm{MeOH}, 0.15 \mathrm{~L} ; \mathrm{MeOH}+0.1 \% \mathrm{TFA}, 0.15 \mathrm{~L}\right)$. Fraction 1D $\left(\mathrm{CHCl}_{3}: \mathrm{MeOH}=7: 1-5: 1,33 \mathrm{mg}\right)$ was suspended in $5 \%$ $\mathrm{MeOH}$ and subjected to ODS open column chromatography $(\varphi 15 \times$ $140 \mathrm{~mm}, \mathrm{MeOH}-\mathrm{H}_{2} \mathrm{O}$ system) at once to give subfractions $2 \mathrm{~A}\left(\mathrm{H}_{2} \mathrm{O}\right.$, $0.02 \mathrm{~L}$ ), 2B (5\% MeOH, $0.02 \mathrm{~L}), 2 \mathrm{C}(10 \% \mathrm{MeOH}, 0.02 \mathrm{~L}), 2 \mathrm{D}(15 \%$ $\mathrm{MeOH}, 0.02 \mathrm{~L}$ ), 2E (20\% MeOH, $0.02 \mathrm{~L}), 2 \mathrm{~F}$ (25\% MeOH, $0.02 \mathrm{~L}), 2 \mathrm{G}$ $(40 \% \mathrm{MeOH}, 0.02 \mathrm{~L}), 2 \mathrm{H}(50 \% \mathrm{MeOH}, 0.02 \mathrm{~L}), 2 \mathrm{I}(\mathrm{MeOH}, 0.02 \mathrm{~L})$, and 2] $(\mathrm{MeOH}+0.1 \% \mathrm{HCOOH}, 0.02 \mathrm{~L})$. Subfraction $2 \mathrm{E}(20 \% \mathrm{MeOH}, 0.7$ $\mathrm{mg}$ ) was regarded as compound $\mathbf{2}(\triangleright$ Fig. 2). A part of fraction $1 \mathrm{H}$ $\left(\mathrm{CHCl}_{3}: \mathrm{MeOH}=3: 1-2: 1,671 \mathrm{mg}\right.$ of $\left.681 \mathrm{mg}\right)$ was subjected to silica gel PSQ 100B column chromatography $\left(\varphi 25 \times 160 \mathrm{~mm}, \mathrm{CHCl}_{3}-\right.$ $\mathrm{MeOH}$ system) to give subfractions $3 \mathrm{~A}-3 \mathrm{I}$. A part of subfraction $3 \mathrm{E}$ $\left(\mathrm{CHCl}_{3}: \mathrm{MeOH}=5: 1,54 \mathrm{mg}\right.$ of $\left.64 \mathrm{mg}\right)$ was subjected to HPLC [COSMOSIL Cholester $(\varphi 10.0 \times 250 \mathrm{~mm})$; eluent: $20 \% \mathrm{MeOH}$; flow rate: $5.0 \mathrm{~mL} / \mathrm{min}$; UV detection: $254 \mathrm{~nm}$ ] to give compound 1 (4.4 mg, $\left.t_{\mathrm{R}} 4.7 \mathrm{~min}\right)$ ( $\triangleright$ Fig. 2).

DMSO and Nob served as the negative and positive controls, respectively, in measuring CRE-mediated transcriptional activity. As can be seen in \ Fig. 3, MEAC induces a powerful increasing action on CRE-mediated transcription in PC12 cells. Also, the BuOH layer showed the strongest activity among the four layers and then was chromatographed on silica gel to afford the active compounds 1 and 2 . The physicochemical properties of the active compounds $\mathbf{1}$ and $\mathbf{2}$ properly correspond to those of adenosine and cordysinin B, respectively (Table S1 and S2) [19, 20]. Cordysinin B was previously isolated from Cordyceps sinensis[20]. Therefore, it is concluded that the major active ingredients of $A$. cordifolia are adenosine and cordysinin $B$, respectively. 


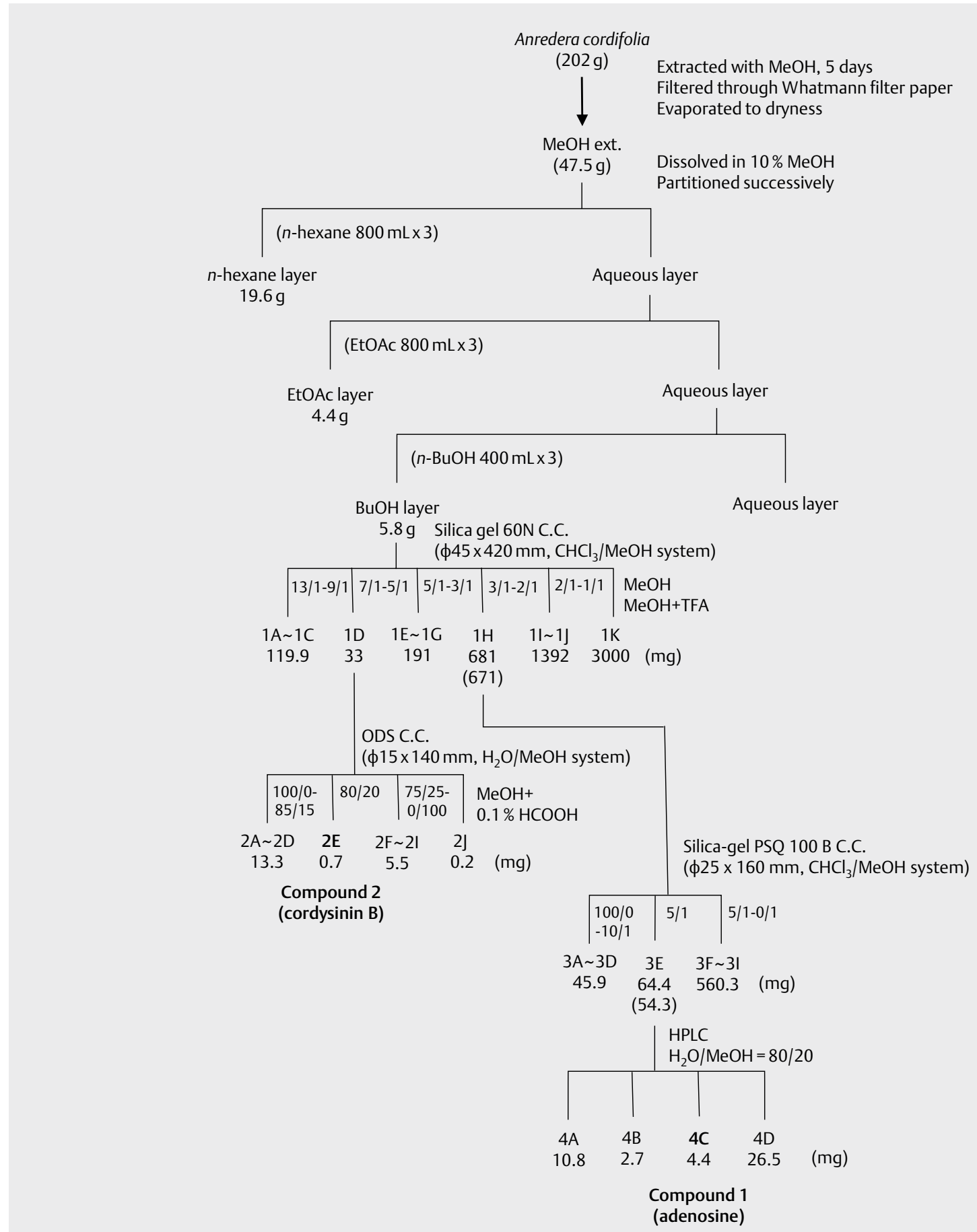

- Fig. 1 Scheme for isolation of pharmacologically active compounds from A. cordifolia.

- Fig. 4 indicates that introducing a methyl group into the $\mathrm{OH}$ group at the $\mathrm{C}-2^{\prime}$ position of adenosine decreases the CRE-mediated transcription activity approximately 100 times. Therefore, these results suggest that the $\mathrm{OH}$ group is important for developing the activity.

To demonstrate the mechanisms responsible for CRE-mediated transcription induction by adenosine and cordysinin B, we used adenosine A receptor antagonists CGS 15943 (a nonselective adenosine $A$ receptor antagonist), DPCPX (an adenosine $A_{1}$ receptor antagonist), SCH 58261 (an adenosine $A_{2 A}$ receptor antagonist), MRS 1754 (an adenosine $A_{2 B}$ receptor antagonist), and MRS 1523 (an adenosine $A_{3}$ receptor antagonist). CRE-mediated transcription induced by adenosine and cordysinin $B$ was blocked by pretreating with CGS 15943, DPCPX, SCH 58261, or MRS 1754, although 
the effect of MRS 1754 on adenosine-induced CRE-mediated transcription was weak ( $\triangleright$ Fig. 5). In contrast, MRS 1523 did not affect CRE-mediated transcription induced by adenosine or cordysinin $B$. These results suggest that adenosine and cordysinin $B$ induce CRE-mediated transcription, at least in part, by $A_{1}, A_{2 A}$, and $A_{2 B}$ receptors.

Conclusively, adenosine and cordysinin $B$ are isolated active ingredients from $A$. cordifolia and possess the activity to induce CREmediated transcription, an important event for memory formation. It is also suggested that these actions are induced, at least in part, by adenosine $A_{1}, A_{2 A}$, and $A_{2 B}$ receptors, but not $A_{3}$ receptor.

\section{Materials and Methods}

\section{Plant material}

A. cordifolia leaves were collected from the hothouse of Sankyo Co., Ltd. in Fuji, Japan from May 2015 to July 2016. The plant material was identified by Dr. Koji Kajima. A voucher specimen was deposi-

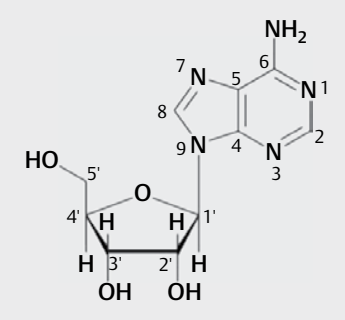

Compound 1 (Adenosine)

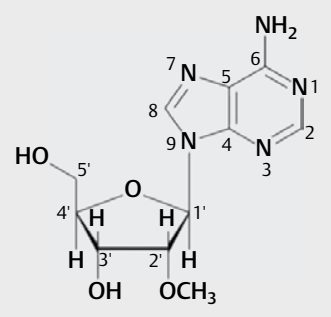

Compound 2 (Cordysinin B) ted at Sankyo Co., Ltd. (SS-U001). A. cordifolia, a perennial Basellaceae native to South America, has been used as a traditional medicine in China and Japan.

\section{General experimental procedures in chemistry}

An ECZ-600 spectrometer (JEOL) was used for NMR spectroscopy and the chemical shift of the NMR solvent was used as an internal standard. An HPLC system (Shimadzu) comprising an SCL-10AVP system controller, LC-20AD pump, DGU-12A online degasser, SIL20A, CTO-10ASVP column oven, SIL-20A autosampler, SPD-M20A PDA detector, and CLASS-VP software was used. The following adsorbents were used for purification: silica gel 60 F254 (0.25 mm; Merck) and silica gel 60 RP-8 F254 S (0.25 mm; Merck) for analytical TLC; Silica gel $60 \mathrm{~N}$ (Kanto), silica gel PSQ 100B, and Chromatrex ODS (Fuji Silysia chemical) for column chromatography; COSMOSIL Cholester $(\varphi 10.0 \times 250$ mm; Nacalai Tesque) for HPLC.

\section{Reagents}

CGS 15943 was obtained from Cayman Chemical. DPCPX, SCH 5826, MRS 1754, and MRS 1523 were purchased from Abcam. Adenosine (purity $\geq 99 \%$ ) and cordysinin B (2'-O-Methyl Adenosine) (purity $\geq 98 \%$ ) were from Sigma-Aldrich and Toronto Research Chemicals, respectively. Nob was extracted and isolated from C. depressa peels as described previously $[11,12]$. The purity of Nob was confirmed to be almost $100 \%$.

\section{Culture of rat pheochromocytoma (PC12) cells}

PC12 cells were grown in DMEM supplemented with $10 \%$ heat-inactivated horse serum (Gibco by Life Technologies), $5 \%$ heat-inactivated fetal bovine serum (Gibco), and $1 \%$ penicillin/streptomycin (Gibco) at $37^{\circ} \mathrm{C}$ in a humidified atmosphere of $95 \%$ air and $5 \% \mathrm{CO}_{2}$.

Fig. 2 Chemical structures of compounds $\mathbf{1}$ (adenosine) and $\mathbf{2}$ (cordysinin B) from the MEAC.

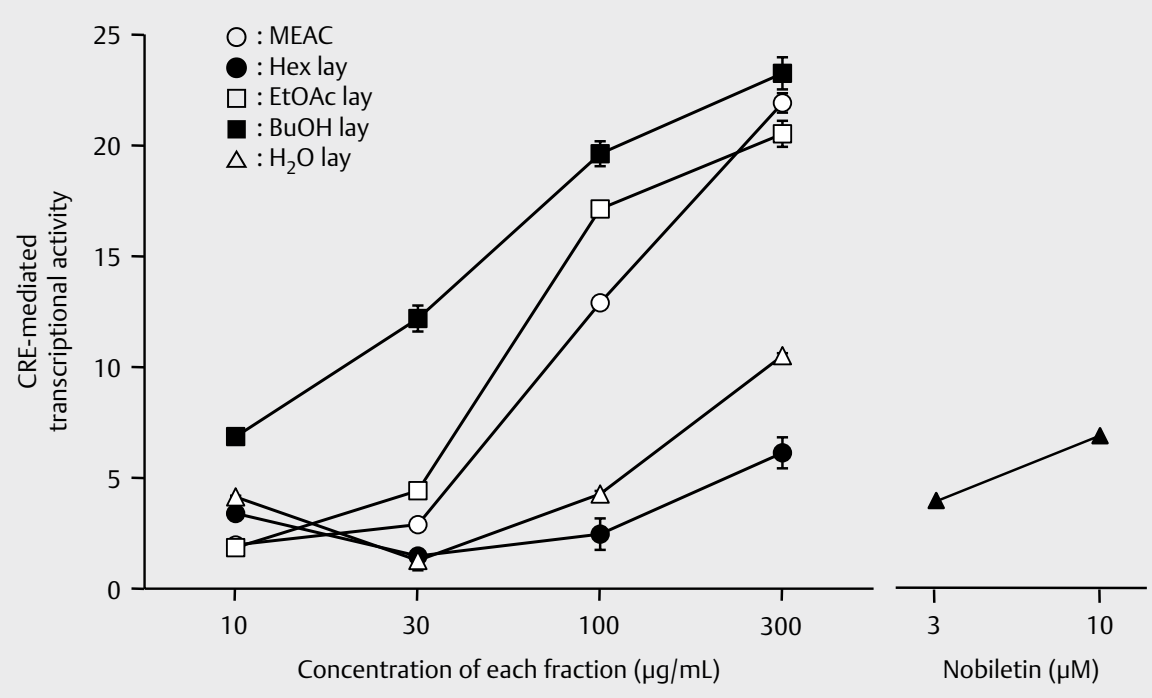

- Fig. 3 Increasing activities of the MEAC and the layer of $n$-hexane (Hex), ethyl acetate (EtOAc), $n$-buthanol (BuOH), or water $\left(\mathrm{H}_{2} \mathrm{O}\right)$ on $\mathrm{CRE}$-mediated transcription in PC12 cells. Data are shown as the mean \pm SEM $(n=4)$. For some data points, error bars are smaller than the symbol size. 


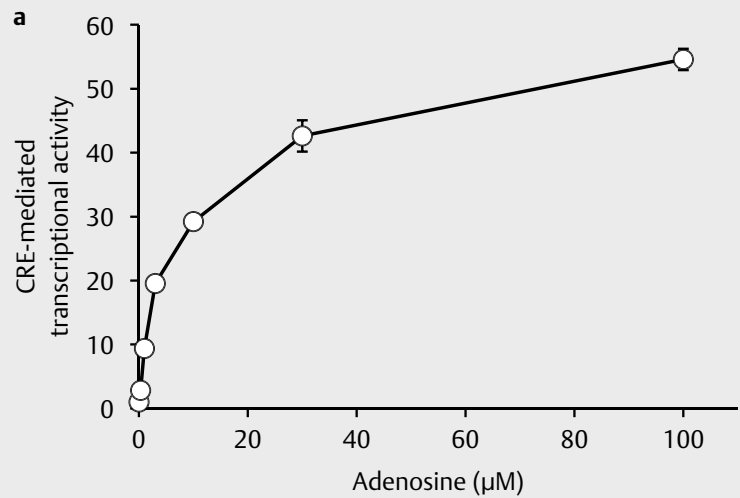

b
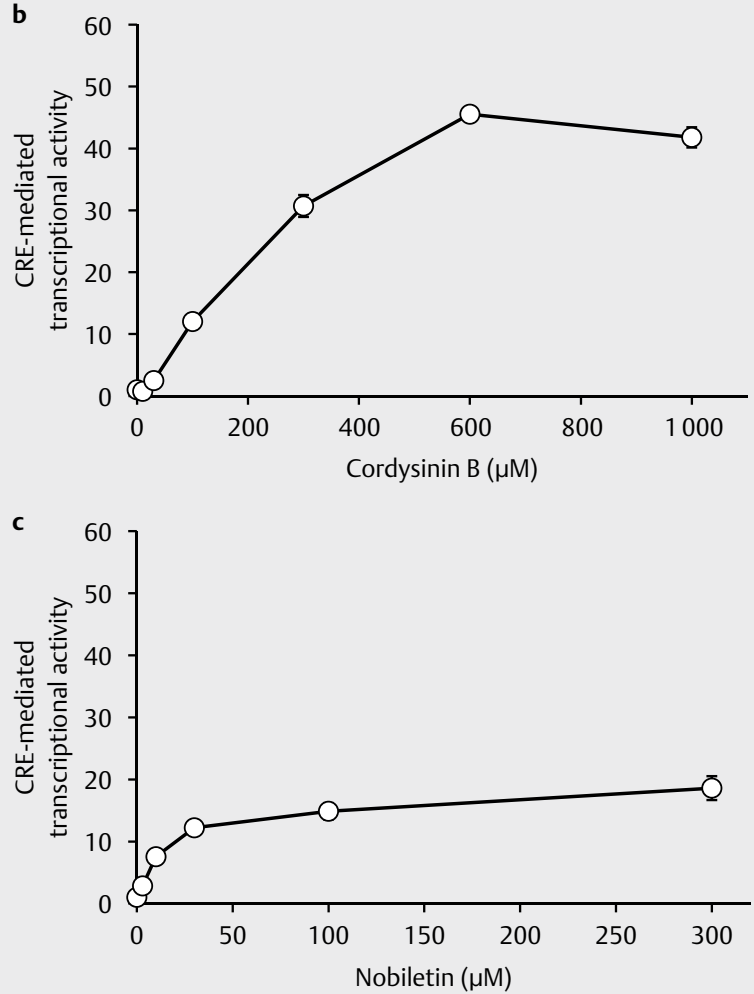

Fig. 4 Concentration-dependent effects of adenosine a, cordysinin B b, and nobiletin c on CRE-mediated transcription in PC12 cells. Data are shown as the mean \pm SEM $(n=4)$. For some data points, error bars are smaller than the symbol size.

\section{Measurements of cyclic AMP-response element- mediated transcriptional activity in PC12 cells}

Transient transfection and the reporter gene assay were prepared as described previously [11]. PC12 cells cultured in 96-well plates $\left(4 \times 10^{4} /\right.$ well) were transfected for $5 \mathrm{~h}$ with $0.2 \mathrm{mg}$ of the reporter plasmid pCRE (Clontech) and $0.04 \mathrm{mg}$ of the transfection efficiency Renilla luciferase phRG-TK plasmid (Promega) using LipofectAMINE (Invitrogen) according to the manufacturer's instructions. After transfection, the medium was replaced with a fresh medium containing advanced DMEM, $1 \%$ horse serum (Gibco), and $1 \%$ fetal bovine serum (Gibco), and the cells were incubated overnight. After incubation, the cells were stimulated for $5 \mathrm{~h}$ with MEAC, adenosi-

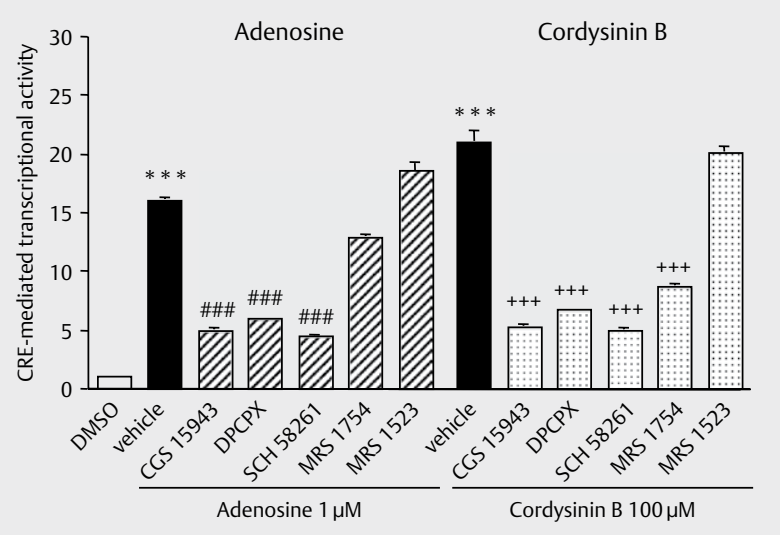

- Fig. 5 Effects of adenosine receptor antagonists on adenosineand cordysinin B-induced enhancement of CRE-mediated transcription in PC12 cells. Data are shown as the mean $\pm \operatorname{SEM}(n=4) .{ }^{*}{ }^{*} \mathrm{P}<0.001$ vs. DMSO-treated control; ${ }^{\# \#} \mathrm{p}<0.001$ vs. adenosine alone-treated group; ${ }^{++} p<0.001$ vs. cordysinin B alone-treated group.

ne, or cordysinin B. In the reporter gene assay, commercially available adenosine standard (Sigma-Aldrich, catalog A4036) and cordysinin B standard (Toronto Research Chemicals, catalog M276150) were used. For experiments using adenosine receptor antagonists, the cells were preincubated with CGS $15943(3 \mu \mathrm{M})$, DPCPX $(0.5 \mu \mathrm{M})$, SCH $58261(3 \mathrm{nM})$, MRS $1754(30 \mu \mathrm{M})$, or MRS 1523 $(1 \mu \mathrm{M})$ for $30 \mathrm{~min}$ before stimulation and then stimulated for $5 \mathrm{~h}$ with adenosine or cordysinin $B$ in the presence of an individual antagonist. Luminescence was measured using a Dual-Luciferase Reporter Assay System according to the manufacturer's instructions (Promega). All treatments were performed in quadruplicate on at least three independent cultures.

\section{Statistical analysis}

The results are expressed as the mean \pm SEM. Data were analyzed using one-way analysis of variance (ANOVA), followed by TukeyKramer test, and $p<0.05$ was considered statistically significant difference.

\section{Supporting information}

${ }^{1} \mathrm{H}$ NMR and MS spectra of compound $1,{ }^{1} \mathrm{H}$ and ${ }^{13} \mathrm{C}$ NMR and MS spectra of compound 2, and tables for comparison of the physicochemical properties between compound 1 and adenosine and those between compound 2 and cordysinin B are available as Supporting information.

\section{Acknowledgments}

The authors are grateful to Mr. Koji Maruyama at Sankyo Co., Ltd. for assistance with preparation of the $A$. cordifolia extract.

\section{Conflict of Interest}

This work was supported by the research fund from Sankyo Co., Ltd.; however, this sponsor had no control over the interpretation, writing, or publication of this work. 


\section{References}

[1] Huang Y, Mucke L. Alzheimer mechanisms and therapeutic strategies. Cell 2012; 148: 1204-1222

[2] Vitolo OV, Sant'Angelo A, Costanzo V, Battaglia F, Arancio O, Shelanski M. Amyloid beta-peptide inhibition of the PKA/CREB pathway and long-term potentiation: reversibility by drugs that enhance CAMP signaling. Proc Natl Acad Sci USA 2002; 99: 13217-13221

[3] Ma QL, Harris-White ME, Ubeda O], Simmons M, Beech W, Lim GP, Teter B, Frautschy SA, Cole GM. Evidence of Abeta- and transgenedependent defects in ERK-CREB signaling in Alzheimer's models. J Neurochem 2007; 103: 1594-1607

[4] Frey U, Huang YY, Kandel ER. Effects of cAMP stimulate a late stage LTP in hippocampal CA1 neurons. Science 1993; 260: 1661-1664

[5] Impey S, Mark M, Villacres EC, Poser S, Chavkin C, Storm DR. Induction of CRE-mediated gene expression by stimuli that generate long-lasting LTP in area CA1 of the hippocampus. Neuron 1996; 16: 973-982

[6] Abel T, Nguyen PV, Barad M, Deuel TA, Kandel ER, Bourtchouladze R. Genetic demonstration of a role for PKA in the late phase of LTP and in hippocampus-based long-term memory. Cell 1997; 88: 615-626

[7] Sweatt JD. Mitogen-activated protein kinases in synaptic plasticity and memory. Curr Opin Neurobiol 2004; 14: 311-317

[8] Kandel ER. The molecular biology of memory: CAMP, PKA, CRE, CREB-1, CREB-2, and CPEB. Mol Brain 2012; 5: 14

[9] Ohizumi Y. Application of physiologically active substances isolated from natural resources to pharmacological studies. Jpn J Pharmacol 1997; 73: 263-289

[10] Li JW, Vederas JC. Drug discovery and natural products: End of an era or an endless frontier? Science 2009; 325: 161-165

[11] Nagase H, Omae N, Omori A, Nakagawasai O, Tadano T, Yokosuka A, Sashida Y, Mimaki Y, Yamakuni T, Ohizumi Y. Nobiletin and its related flavonoids with CRE-mediated transcription-stimulating and neuritegenic activities. Biochem Biophys Res Commun 2005; 337: $1330-1336$
[12] Nagase H, Yamakuni T, Matsuzaki K, Maruyama Y, Kasahara J, Hinohara Y, Kondo S, Mimaki Y, Sashida Y, Tank AW, Fukunaga K, Ohizumi Y. Mechanism of neurotrophic action of nobiletin in PC12D cells. Biochemistry 2005; 44: 13683-13691

[13] Nakajima A, Ohizumi Y, Yamada K. Anti-dementia activity of nobiletin, a citrus flavonoid: A review of animal studies. Clin Psychopharmacol Neurosci 2014; 12: 75-82

[14] Nakajima A, Ohizumi Y. Potential benefits of nobiletin, a citrus flavonoid, against Alzheimer's disease and Parkinson's disease. Int J Mol Sci 2019; 20: 3380

[15] Nakajima A, Hachiro M, Kajima K, Ohizum Y. Anredera cordifolia extract improves MK-801-induced memory impairment in mice. Pharmacometrics 2020; 98: 27-30

[16] Yuniarti WM, Lukiswant BS. Effects of herbal ointment containing the leaf extracts of Madeira vine (Anredera cordifolia (Ten.) Steenis) for burn wound healing process on albino rats. Vet World 2017; 10 : 808-813

[17] Leliqia NPE, Sukandar EY, Fidrianny I. Overview of efficacy, safety and phytochemical study of Anredera cordifolia (TEN.) steenis. Pharmacologyonline 2017; 1: 124-131

[18] Ohizumi Y. [A new strategy for prevention and finctional therapeutic methods for dementia --approach using natural products]. . Yakugaku Zasshi 2015; 135: 449-464

[19] Ciuffreda P, Casati S, Manzocchi A. Complete 1H and 13C NMR spectral assignment of a $\alpha$ - and $\beta$-adenosine, 2 -deoxyadenosine and their acetate derivatives. Magn Reson Chem 2007; 45: 781-784

[20] Yang ML, Kuo PC, Hwang TL, Wu TS. Anti-inflammatory principles from Cordyceps sinensis. J Nat Prod 2011; 74: 1996-2000 